\title{
Why and how to use the body's own stem cells for regeneration in musculoskeletal disorders: a primer
}

\author{
John P. Furia', Mark A. Lundeen², Jason L. Hurd³ ${ }^{3}$ David A. Pearce ${ }^{4,5,6}$, Christopher Alt7, ${ }^{7,8}$, Eckhard U. Alt ${ }^{6,7,9}$, \\ Christoph Schmitz ${ }^{8^{*}}$ (D) and Nicola Maffulli $i^{10,11,12}$
}

\begin{abstract}
Background: Recently, the management of musculoskeletal disorders with the patients' own stem cells, isolated from the walls of small blood vessels, which can be found in great numbers in the adipose tissue, has received considerable attention. On the other hand, there are still misconceptions about these adipose-derived regenerative cells (ADRCs) that contain vascular-associated pluripotent stem cells (vaPS cells) in regenerative medicine.
\end{abstract}

Methods: Based on our previous publications on this topic, we have developed a concept to describe the significance of the ADRCs/vaPS cells in the field of orthobiologics as briefly as possible and at the same time as precisely as possible.

Results: The ADRCs/vaPS cells belong to the group of orthobiologics that are based on autologous cells. Because the latter can both stimulate a patient's body's localized self-healing power and provide new cells that can integrate into the host tissue during the healing response when the localized self-healing power is exhausted, this group of orthobiologics appears more advantageous than cell-free orthobiologics and orthobiologics that are based on allogeneic cells. Within the group of orthobiologics that are based on autologous cells, enzymatically isolated, uncultured ADRCs/vaPS cells have several advantages over non-enzymatically isolated cells/microfragmented fat as well as over uncultured bone marrow aspirate concentrate and cultured cells (adipose-derived stem cells, bone marrow-derived mesenchymal stem cells).

Conclusions: The use of ADRCs/vaPS cells can be seamlessly integrated into modern orthopedic treatment concepts, which can be understood as the optimization of a process which - albeit less efficiently —also takes place physiologically. Accordingly, this new safe and effective type of treatment is attractive in terms of holistic thinking and personalized medicine.

Keywords: Adipose-derived regenerative cells, ADRCs, Adipose-derived stem cells, ADSCs, Bone regeneration, Cartilage regeneration, Efficacy, Point of care treatment, Stem cell, Tendon healing without scar formation, Tendon regeneration, vaPS cells

*Correspondence: christoph_schmitz@med.uni-muenchen.de

${ }^{8}$ Institute of Anatomy, Faculty of Medicine, LMU Munich, Pettenkoferstr. 11, 80331 Munich, Germany

Full list of author information is available at the end of the article

\section{Background}

When talking about regenerative medicine in general and stem cells in particular, it is necessary to clarify at least some of the aspects of the physiology of these cells. Many lay people automatically think of embryonic stem cells when "stem cell therapy" is mentioned, original author(s) and the source, provide a link to the Creative Commons licence, and indicate if changes were made. The images or other third party material in this article are included in the article's Creative Commons licence, unless indicated otherwise in a credit line to the material. If material is not included in the article's Creative Commons licence and your intended use is not permitted by statutory regulation or exceeds the permitted use, you will need to obtain permission directly from the copyright holder. To view a copy of this licence, visit http://creativecommons.org/licenses/by/4.0/. The Creative Commons Public Domain Dedication waiver (http://creativeco mmons.org/publicdomain/zero/1.0/) applies to the data made available in this article, unless otherwise stated in a credit line to the data. 
but in reality currently no clinical application exists for embryonic stem cells. This is based not only on ethical concerns and the risk of development of teratomas (i.e. tumors derived from embryonic stem cells), but also on the allogeneic nature of embryonic cells [1,2]. Even for so-called induced pluripotent stem cells (iPS cells), the development of which was honored with a Nobel Prize for Medicine in 2012, clinical applications are missing, not only for the complexity of the procedure, but particularly based on the risk of malignant transformation of these cells (i.e. the development of cancer) [1, 2]. For completeness, the transplantation of stem cells from the bone marrow in leukemia [3] should be mentioned, but this will not be discussed here further.

Under physiological conditions, maintenance and restoration of organ function is mostly achieved by local cells, including so-called tissue resident stem cells [4, 5]). However, in the event of acute trauma or disease, the sudden demand of new cells during the healing response may exceed the plasticity of the local cell populations. Furthermore, the ability of the tissue resident stem cells to re-enter the cell cycle and to asymmetrically divide is limited, which eventually limits the extent of self-renewal (and, thus, the self-healing power of the body) following major loss of cells in damaged tissue, such as during aging, after an infarction or with non-healing wounds etc.

On the other hand, there is a further type of stem cells present in the adult body, with the potential to develop (differentiate) into cells of all three embryonic germ layers (ectoderm, mesoderm, endoderm) [1, 2, 6]. These cells, which are termed vascular associated pluripotent stem cells (vaPS cells), are located in the walls of small blood vessels [1, 2]. Since blood vessels are the basis for the formation of tissue and organs in a developing body, these vaPS cells are also found in every organ of the adult body, including adipose tissue, heart, skin, bone marrow, skeletal muscle and tendons [1]. It is currently unknown to which extent these vaPS cells participate in the physiological maintenance and restoration of organ functions. In any case, unlike embryonic stem cells and iPS cells, the vaPS cells do not have their own, intrinsic program for the formation of new tissue, but become active in response to specific signals released and transmitted by diseased tissue [1]. Considering this fundamental difference, the vaPS cells have become an attractive option for regenerative therapy purposes without the risk of malignant transformation.

As long as the aforementioned local self-healing power of the body is sufficient to restore physiological body structures and functions in the event of trauma or disease, all treatment efforts should primarily focus on this. A variety of methods, including but not limited to physiotherapy, osteopathy, extracorporeal shock wave therapy (ESWT) [7], laser therapy [8] and the injection of platelet-rich plasma (PRP) [9], can make valuable contributions through stimulation of local regeneration.

However, a patient's body's localized self-healing power can eventually exhaust. As a consequence, physiological body structures and functions can no longer be restored by the local stem cell pool. For example, in chronic wounds cells obtained during surgical wound debridement can no longer multiply to the extent that is necessary for adequate wound healing [10]. If a similar condition exists with damages in the musculoskeletal system, further conservative measures will have a high risk of failure. In essence, one can treat the patient with as much physiotherapy, ESWT, laser or other modalities as desired, and one can inject as much PRP as one wishes and patients request: these interventions will not work, or they only work to a limited extent because the cells that are supposed to effect the repair are simply not there any longer or cannot adequately react to stimulation.

This is exactly where the targeted use of the body's own vaPS cells comes into play, because they can be harvested and isolated from the body's own adipose tissue. Practically every one of us has a certain amount of body fat, which the organism can spare, and which can be obtained by mini-liposuction on the abdomen, the flanks or the thighs in an outpatient procedure with low risk and without general anesthesia; $100 \mathrm{~g}$ of adipose tissue are sufficient in most instances. Adipose derived regenerative cells (ADRCs) (which contain the vaPS cells [1]) can then be isolated from the adipose tissue using relatively simple technologies, whereby enzymatic processes are overall clearly superior to other, non-enzymatic processes [6]. It should be considered that some of the nonenzymatic processes may pose a risk that the ADRCs are not or not completely released from the surrounding connective tissue (e.g. [11]), limiting their effectiveness and increasing the risk of occlusions of small blood vessels if corresponding tissue fragments reach small blood vessels. Figure 1 shows ADRCs enzymatically isolated from human adipose tissue.

ADRCs are a mixture of cells including vaPS cells, progenitor cells, cells of the walls of the blood vessels (pericytes, endothelial cells, endothelial precursor cells and fibroblasts) and blood cells. Until a few years ago, it was thought that it was important to isolate the stem cells from the ADRCs in the next step and to multiply them in the laboratory (i.e. in cell culture) before using them therapeutically, resulting in so-called adipose derived stem cells (ADSCs). However, there is now good evidence that uncultured ADRCs are superior to cultured ADSCs for regeneration of tendons and bone [13, 14]. One of the reasons for this is that uncultured ADRCs contain 


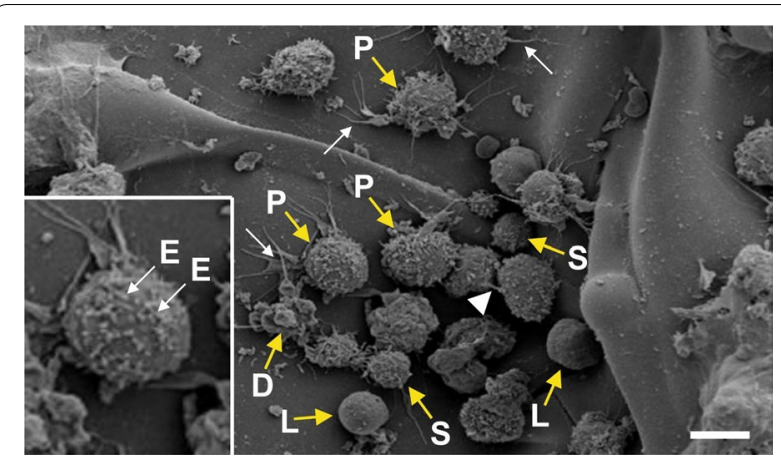

Fig. 1 Scanning electron micrograph of ADRCs obtained from human abdominal adipose tissue (figure taken from [1] and with kind permission [12]). P, precursor cells; $S$, small cells; $D$, dying cells; $L$, lymphocytes; E, exosomes. The white arrows point to actin filaments and the white arrowhead to a microchannel between two cells. The bar corresponds to $10 \mu \mathrm{m}$ ( $20 \mu \mathrm{m}$ in the enlarged section)

cell types that can no longer be found in cultured ADSCs [15]. In addition, the conditions in the cell culture are at least not improving the function of the cells [16].

The use of fresh, uncultured ADRCs instead of cultured ADSCs has two other important advantages for the patient: (1) as the cells are not cultivated in a laboratory, the possible risk of contamination by bacteria and viruses is avoided, and (2) treatment with uncultured ADRCs is a real point of care procedure. Within a very short time span and in the same surgical setting, the adipose tissue can be obtained by mini-liposuction and the ADRCs can be injected to the point in the body where they are needed.

As evidenced by a large number of animal studies, treatment of pathologies of the musculoskeletal system with ADRCs is safe (i.e. does not lead to the development of cancer and other undesirable side effects) and treatment with ADRCs or ADSCs leads to a significant improvement of the structure and function of a damaged organ or tissue (e.g. [17-19]). Based on these highly positive results, treatment of human patients specifically with uncultured ADRCs started a few years ago. At this point, we would particularly like to address the treatment of symptomatic, partial-thickness rotator cuff tear (sPTRCT). Specifically, in a feasibility study approved by the U.S. Food and Drug Administration (FDA), we demonstrated for the first time that in patients suffering from SPTRCT who had not responded to over six weeks of conservative management (indicating that the self-healing power of the body had been exhausted), a single application of ADRCs led to rapid and long-lasting improvement in the clinical situation, with an improvement in the American Shoulder and Elbow Surgeons Standardized Shoulder Assessment Form (ASES) total score from $58.7 \pm 19.2$ (mean \pm standard error of the mean) before treatment to $86.1 \pm 4.9$ at 24 weeks post treatment and $89.4 \pm 4.9$ one year post treatment [20] (the maximum ASES total score with complete freedom from pain and unrestricted mobility of the shoulder is 100). The results of a control group of patients treated with corticosteroid injections (a standard therapy for the condition at hand) were statistically significantly worse than the results of the patients treated with ADRCs (in the control group the mean ASES score was 50.6 \pm 6.7 before treatment, $60.8 \pm 6.2$ at 24 weeks post treatment and $68.4 \pm 4.4$ one year post treatment [20]). In retrospect, the poor performance of the standard therapy (injection of corticosteroid) is not really surprising when it becomes clear that, when the local self-healing power of the body is exhausted, the injection of corticosteroids certainly leads to reduction of inflammation (and thus pain relief) in the affected shoulder, but cannot result in healing.

On the other hand, this study [20] could not answer the question of what exactly the ADRCs had done to the partial ruptures of the supraspinatus tendon. However, one co-author of this paper (E.A.) suffered from sPTRCT caused by a bicycle accident about five years ago and was treated with his own ADRCs. As part of a so-called medical self-test, for the first time worldwide a biopsy was taken from the partially ruptured supraspinatus tendon ten weeks after it had been treated with ADRCs. The biopsy then was examined in the laboratory of another co-author of this paper (C.S.) with a multitude of immunohistochemical markers [21]. We were able to demonstrate that regeneration without scar formation had taken place in the damaged tendon treated with ADRCs [22]. The special feature of this finding is that this type of regeneration had so far only been observed in fetal tendons [23].

In the meantime, a large number of patients suffering from various pathologies of the musculoskeletal system have been successfully treated with ADRCs both in individual healing attempts and controlled clinical trials, with sPTRCT, cartilage defects of the knee and osteoarthritis of the facet joints [1, 24-26] being the most important indications.

Of note, no special follow-up treatment is necessary after the application of ADRCs. Accordingly, patients can return to routine care immediately after the application of ADRCs.

In summary, the use of ADRCs in treatments of pathologies of the musculoskeletal system seamlessly fits into modern orthopedic treatment concepts. The patients receive treatment with their own body's self-healing power, which is just recovered and transferred from one "healthy" site to another site of the body in need for 
repair. This reflects a natural and intrinsically existing mechanism of the body, to mobilize stem cells from adipose tissue (however in often not sufficient amounts) and transfer cells for "self-healing" to damaged organs and tissue in need for repair [27].

The ADRCs/vaPS cells belong to the larger field of orthobiologics, which have recently been addressed in a number of comprehensive reviews (e.g. [28-30]) (Table 1).

According to the above, orthobiologics can generally be classified serving the following needs: (1) stimulating a patient's body's localized self-healing power, and (2) providing new cells that can integrate into the host tissue during the healing response when the localized selfhealing power is exhausted.

Of note, all cell-free orthobiologics as well as all orthobiologics that are based on allogeneic cells can in principle only address the former, because differentiated cells derived from allogeneic stem cells are recognized by the immune system of the host organism and removed [48]. Furthermore, repeated intra-articular injection of allogeneic stem cells in an equine model led to adverse

Table 1 Overview on biologics according to the U.S. Food and Drug Administration

\begin{tabular}{ll}
\hline Cell-free orthobiologics & Examples \\
Platelet rich plasma & {$[31]$} \\
Exosomes & {$[32]$} \\
Amniotic fluid & {$[33]$} \\
Orthobiologics that are based on allogeneic cells & \\
Allogeneic mesenchymal stem cells (MSCs) derived from & {$[34-36]$} \\
respectively placenta, umbilical cord or umbilical cord blood & \\
Allogeneic bone marrow-derived MSCs (BM-MSCs) & {$[37]$} \\
Allogeneic adipose-derived stem cells (ADSCs) & {$[38]$} \\
Orthobiologics that are based on autologous cells & \\
Autologous ADRCs & {$[20]$} \\
Autologous ADSCs & {$[39]$} \\
Autologous, micro-fragmented fat (from liposuction) & {$[40]$} \\
Bone marrow aspirate concentrate & {$[41]$} \\
Autologous BM-MSCs & {$[42]$} \\
Chondrocyte transplants & {$[43]$} \\
Autologous, activated peripheral blood stem cells & {$[44]$} \\
Other orthobiologics & \\
Tissue-engineered patches & {$[45]$} \\
Cadaver grafts & {$[46]$} \\
Modulation of the immune system & {$[47]$} \\
Other biologics with currently limited or no relevance in ortho- & \\
pedics & \\
Recombinant therapeutic proteins & \\
Allergenics & \\
Vaccines & \\
\hline &
\end{tabular}

responses, suggesting immune recognition of allogeneic stem cells upon a second exposure [49]. These effects were not observed after repeated intra-articular injection of autologous stem cells in the same model [49].

In contrast, orthobiologics that are based on autologous cells can address both the former and the latter, which makes them appear more advantageous than cellfree orthobiologics and orthobiologics that are based on allogeneic cells. It is obvious that this must be demonstrated in adequate, randomized controlled trials in the future (e.g. [50]).

Within the group of orthobiologics based on autologous cells, one has to differentiate between point of care procedures (e.g. uncultured ADRCs/vaPS cells and bone marrow aspirate concentrate (BMAC)) and procedures that include cell culturing (e.g. cultured ADSCs and bone marrow-derived mesenchymal stem cells). The disadvantages of the procedures that include cell culturing (selection of cells, exposing cells with the conditions of cell culture) are addressed above and explained in detail in the literature $[2,16]$. The same applies to the advantages of ADRCs over BMAC (higher risk of opening bone marrow; orders of magnitude fewer stem cells in the same amount of BMAC compared with ADRCs) [2].

All mentioned procedures may be combined with tissue-engineered patches and/or cadaver grafts, which however requires surgical procedures to apply them. In addition, all cells that are derived from cell culture (including chondrocyte transplants) do not meet the criteria of 'minimally manipulated' as defined in U.S. Code of Federal Regulations 21 CFR 1271.10(a) (details and consequences are provided in [2]). The European Medicines Agency considers cells that are derived from cell culture as an Advanced Therapy Medicinal Product (ATMP) (details are also provided in [2]).

Finally, there remains one important question: why cannot the organism physiologically mobilize the vaPS cells in sufficient quantity from a distant reservoir in the walls of small blood vessels and bring them to sites where the self-healing power is exhausted? One possible answer is that degenerative processes of tissues of the musculoskeletal system (if they were not induced, for example, by sports accidents, etc.) in the vast majority of cases do not appear until an age that has never been subject to optimization pressure in evolution. In this regard, our concept to "give nature a helping hand" to optimize an intrinsic process that naturally exists (albeit at a less sufficient level) is safe and efficient and thus appears logical and recommendable.

\section{Abbreviations}

ADRCs: Adipose derived regenerative cells; ADSCs: Adipose derived stem cells; ASES: American Shoulder and Elbow Surgeons Standardized Shoulder 
Assessment Form; BMAC: Bone marrow aspirate concentrate; ESWT: Extracorporeal shock wave therapy; FDA: U.S. Food and Drug Administration; iPS cells: Induced pluripotent stem cells; vaPS cells: Vascular associated pluripotent stem cells; PRP: Platelet-rich plasma; SPTRCT: Symptomatic, partial-thickness rotator cuff tear.

\section{Acknowledgements}

We would like to give special thanks to the patients whose data were analyzed in this study for their cooperation and support, and Kathryn Pohlson and Tiffany Facile (both at Sanford Health, Sioux Falls, SD, USA) for very fruitful programmatical contributions.

\section{Authors' contributions}

EA and CS designed the study. CS produced an initial draft of the manuscript. $J F, M L, J H, N M$ and CA contributed enhanced and optimized the manuscript. All authors have read and approved the final submitted manuscript.

\section{Funding}

Not applicable.

\section{Availability of data and materials}

The data that support the findings of this study are available from the corresponding author.

\section{Declarations}

\section{Ethics approval and consent to participate}

Not applicable.

\section{Consent for publication}

Not applicable.

\section{Competing interests}

EA is Executive Chair of InGeneron, Inc. (Houston, TX, USA). CA is Director of Medical and Scientific Affairs of InGeneron. CS is Advisory Medical Director of InGeneron. However, InGeneron had no role in study design, data collection and analysis, interpretation of the data, and no role in the decision to publish and write this manuscript. No other potential conflicts of interest relevant to this article were reported.

\section{Author details}

${ }^{1}$ SUN Orthopedics of Evangelical Community Hospital, Lewisburg, PA, USA. ${ }^{2}$ Sanford Orthopedics \& Sports Medicine Fargo, Fargo, ND, USA. ${ }^{3}$ Sanford Orthopedics \& Sports Medicine Sioux Falls, Sioux Falls, SD, USA. ${ }^{4}$ Sanford Research, Sioux Falls, SD, USA. ${ }^{5}$ Sanford Health, Sioux Falls, SD, USA. ${ }^{6}$ Sanford School of Medicine, University of South Dakota, Sioux Falls, SD, USA. ${ }^{7}$ InGeneron, Inc., TX, Houston, USA. ${ }^{8}$ Institute of Anatomy, Faculty of Medicine, LMU Munich, Pettenkoferstr. 11, 80331 Munich, Germany. ${ }^{9}$ Isarklinikum, Munich, Germany. ${ }^{10}$ Department of Musculoskeletal Disorders, Faculty of Medicine and Surgery, University of Salerno, Salerno, Italy. ${ }^{11}$ Centre for Sports and Exercise Medicine, Barts and The London School of Medicine and Dentistry, Mile End Hospital, Queen Mary University of London, London, England. ${ }^{12}$ School of Pharmacy and Bioengineering, Guy Hilton Research Centre, Keele University School of Medicine, Stoke on Trent, England.

Received: 11 November 2021 Accepted: 3 January 2022

Published online: 21 January 2022

\section{References}

1. Alt EU, Schmitz C, Bai X. Perspective: Why and how ubiquitously distributed, vascular-associated, pluripotent stem cells in the adult body (vaPS Cells) are the next generation of medicine. Cells. 2021;10(9):2303. https:// doi.org/10.3390/cells10092303.

2. Alt EU, Winnier G, Haenel A, Rothoerl R, Solakoglu O, Alt C, Schmitz C. Towards a comprehensive understanding of UA-ADRCs (uncultured, autologous, fresh, unmodified, adipose derived regenerative cells, isolated at point of care) in regenerative medicine. Cells. 2020;9(5):1097. https://doi.org/10.3390/cells9051097.
3. Tian H, Qu Q, Liu L, Wu D. Advances in stem cell therapy for leukemia. Curr Stem Cell Res Ther. 2016;11(2):158-65. https://doi.org/10.2174/ $1574888 \times 10666151019120217$.

4. Nature portfolio stem cells [cited 14 October 2021]. https://www.nature. com/subjects/stem-cells.

5. Ruzzini L, Abbruzzese F, Rainer A, Longo UG, Trombetta M, Maffulli N, Denaro V. Characterization of age-related changes of tendon stem cells from adult human tendons. Knee Surg Sports Traumatol Arthrosc. 2014;22(11):2856-66. https://doi.org/10.1007/s00167-013-2457-4.

6. Winnier GE, Valenzuela N, Peters-Hall J, Kellner J, Alt C, Alt EU. Isolation of adipose tissue derived regenerative cells from human subcutaneous tissue with or without the use of an enzymatic reagent. PLoS ONE. 2019;14(9):e0221457. https://doi.org/10.1371/journal.pone.0221457.

7. Schmitz C, Császár NB, Milz S, Schieker M, Maffulli N, Rompe JD, Furia JP. Efficacy and safety of extracorporeal shock wave therapy for orthopedic conditions: a systematic review on studies listed in the PEDro database. Br Med Bull. 2015;1 16(1):115-38. https://doi.org/10.1093/bmb/ldv047.

8. Schmitz C. Improving extracorporeal shock wave therapy with 904 or 905 nm pulsed, high power laser pretreatment. Preprints 2021: 202101013. https://doi.org/10.20944/preprints202101.0138.v1 [cited 14 October 2021]. https://www.preprints.org/manuscript/202101.0138/v1.

9. Andia I, Martin Jl, Maffulli N. Advances with platelet rich plasma therapies for tendon regeneration. Expert Opin Biol Ther. 2018;18(4):389-98. https://doi.org/10.1080/14712598.2018.1424626.

10. Konstantinow A, Arnold A, Djabali K, Kempf W, Gutermuth J, Fischer T, Biedermann T. Therapy of ulcus cruris of venous and mixed venous arterial origin with autologous, adult, native progenitor cells from subcutaneous adipose tissue: a prospective clinical pilot study. J Eur Acad Dermatol Venereol. 2017;31(12):2104-18. https://doi.org/10.1111/jdv.14489.

11. van Dongen JA, Stevens HP, Parvizi M, van der Lei B, Harmsen MC. The fractionation of adipose tissue procedure to obtain stromal vascular fractions for regenerative purposes. Wound Repair Regen. 2016;24(6):9941003. https://doi.org/10.1111/wrr.12482.

12. Schmitz C, Alt EU. Stem cell therapy [cited 14 October 2021]. https://sport aerztezeitung.com/rubriken/therapie/1227/stammzellentherapie/.

13. Polly SS, Nichols AEC, Donnini E, Inman DJ, Scott TJ, Apple SM, Werre SR, Dahlgren LA. Adipose-derived stromal vascular fraction and cultured stromal cells as trophic mediators for tendon healing. J Orthop Res. 2019;37(6):1429-39. https://doi.org/10.1002/jor.24307.

14. Nyberg E, Farris A, O'Sullivan A, Rodriguez R, Grayson W. Comparison of stromal vascular fraction and passaged adipose-derived stromal/ stem cells as point-of-care agents for bone regeneration. Tissue Eng A. 2019;25(21-22):1459-69. https://doi.org/10.1089/ten.TEA.2018.0341.

15. Mitchell JB, McIntosh K, Zvonic S, Garrett S, Floyd ZE, Kloster A, Di Halvorsen Y, Storms RW, Goh B, Kilroy G, Wu X, Gimble JM. Immunophenotype of human adipose-derived cells: temporal changes in stromal-associated and stem cell-associated markers. Stem Cells. 2006;24(2):376-85. https://doi.org/10.1634/stemcells.2005-0234.

16. Cossu G, Birchall M, Brown T, De Coppi P, Culme-Seymour E, Gibbon S, Hitchcock J, Mason C, Montgomery J, Morris S, Muntoni F, Napier D, Owji N, Prasad A, Round J, Saprai P, Stilgoe J, Thrasher A, Wilson J. Lancet commission: stem cells and regenerative medicine. Lancet. 2018;391(10123):883-910. https://doi.org/10.1016/S0140-6736(17) 31366-1.

17. Chen HS, SuYT, Chan TM, Su YJ, Syu WS, Harn HJ, Lin SZ, Chiu SC. Human adipose-derived stem cells accelerate the restoration of tensile strength of tendon and alleviate the progression of rotator cuff injury in a rat model. Cell Transplant. 2015;24(3):509-20. https://doi.org/10.3727/09636 8915X686968.

18. Dykstra JA, Blue ED, Negrão de Assis PL, Weimer JM, Kota DJ. Human adipose-derived stromal vascular fraction: characterization, safety and therapeutic potential in an experimental mouse model of articular injury. J Stem Cells Regen Med. 2020;16(1):16-25. https://doi.org/10.46582/jsrm. 1601004

19. Haenel A, Ghosn M, Karimi T, Vykoukal J, Shah D, Valderrabano M, Schulz DG, Raizner A, Schmitz C, Alt EU. Unmodified autologous stem cells at point of care for chronic myocardial infarction. World J Stem Cells. 2019;11(10):831-58. https://doi.org/10.4252/wjsc.v11.i10.831.

20. Hurd JL, Facile TR, Weiss J, Hayes M, Hayes M, Furia JP, Maffulli N, Winnier GE, Alt C, Schmitz C, Alt EU, Lundeen M. Safety and efficacy of treating symptomatic, partial-thickness rotator cuff tears with 
fresh, uncultured, unmodified, autologous adipose-derived regenerative cells (UA-ADRCs) isolated at the point of care: a prospective, randomized, controlled first-in-human pilot study. J Orthop Surg Res. 2020;15(1):122. https://doi.org/10.1186/s13018-020-01631-8.

21. Alt E, Rothoerl R, Hoppert M, Frank HG, Wuerfel T, Alt C, Schmitz C. First immunohistochemical evidence of human tendon repair following stem cell injection: a case report and review of literature. World J Stem Cells. 2021;13(7):944-70. https://doi.org/10.4252/wjsc.v13.i7.944.

22. Galatz LM, Gerstenfeld L, Heber-Katz E, Rodeo SA. Tendon regeneration and scar formation: the concept of scarless healing. J Orthop Res. 2015;33(6):823-31. https://doi.org/10.1002/jor.22853.

23. Beredjiklian PK, Favata M, Cartmell JS, Flanagan CL, Crombleholme $T M$, Soslowsky LJ. Regenerative versus reparative healing in tendon: a study of biomechanical and histological properties in fetal sheep. Ann Biomed Eng. 2003;31(10):1143-52. https://doi.org/10.1114/1.1616931.

24. Hurd J. Autologous adult adipose-derived regenerative cell injection into chronic partial-thickness rotator cuff tears. ClinicalTrials.gov Identifier: NCT03752827 [cited 14 October 2021]. https://www.clinicaltrials. gov/ct2/show/NCT03752827.

25. Pearce DA. A disease-based treatment study for diagnosed osteoarthritis utilizing adipose-derived regenerative cells. ClinicalTrials.gov Identifier: NCT04405297 [cited 28 October 2021]. www.clinicaltrials.gov/ct2/ show/NCT04405297.

26. Boetel T. Safety of adipose-derived regenerative cells injection for treatment of osteoarthritis of the facet joint. ClinicalTrials.gov Identifier: NCT035137317 [cited 28 October 2021]. www.clinicaltrials.gov/ct2/ show/NCT035137317.

27. Naaijkens BA, Krijnen PA, Meinster E, ter Horst EN, Vo K, Musters RJ, Kamp O, Niessen HW, Juffermans LJ, van Dijk A. Acute myocardial infarction does not affect functional characteristics of adipose-derived stem cells in rats, but reduces the number of stem cells in adipose tissue. Cell Tissue Res. 2015;362(3):623-32. https://doi.org/10.1007/ s00441-015-2239-z.

28. Obana KK, Schallmo MS, Hong IS, Ahmad CS, Moorman CT 3rd, Trofa DP, Saltzman BM. Current trends in orthobiologics: an 11-year review of the orthopaedic literature. Am J Sports Med. 2021. https://doi.org/10. 1177/03635465211037343.

29. Condron NB, Kester BS, Tokish JM, Zumstein MA, Gobezie R, Scheibel $M$, Cole BJ. Nonoperative and Operative soft-tissue, cartilage, and bony regeneration and orthopaedic biologics of the shoulder: an Orthoregeneration Network (ON) foundation review. Arthroscopy. 2021;37(10):3200-18. https://doi.org/10.1016/j.arthro.2021.06.033.

30. Noback PC, Donnelley CA, Yeatts NC, Parisien RL, Fleischli JE, Ahmad CS, Moorman CT, Trofa DP, Saltzman BM. Utilization of orthobiologics by sports medicine physicians: a survey-based study. J Am Acad Orthop Surg Glob Res Rev. 2021;5(1):e20.00185. https://doi.org/10. 5435/JAAOSGlobal-D-20-00185.

31. Reurink G, Goudswaard GJ, Moen MH, Weir A, Verhaar JA, Bierma-Zeinstra SM, Maas M, Tol JL, Dutch Hamstring Injection Therapy (HIT) Study Investigators. Platelet-rich plasma injections in acute muscle injury. N Engl J Med. 2014;370(26):2546-7. https://doi.org/10.1056/NEJMc14023 40.

32. Connor DE, Paulus JA, Dabestani PJ, Thankam FK, Dilisio MF, Gross RM, Agrawal DK. Therapeutic potential of exosomes in rotator cuff tendon healing. J Bone Miner Metab. 2019;37(5):759-67. https://doi.org/10. 1007/s00774-019-01013-z.

33. Bhattacharya N. Clinical use of amniotic fluid in osteoarthritis: a source of cell therapy. Transplantation. 2011;90:395-403.

34. KhalifehSoltani S, Forogh B, Ahmadbeigi N, HadizadehKharazi H, Fallahzadeh K, Kashani L, Karami M, Kheyrollah Y, Vasei M. Safety and efficacy of allogenic placental mesenchymal stem cells for treating knee osteoarthritis: a pilot study. Cytotherapy. 2019;21(1):54-63. https://doi. org/10.1016/j.jcyt.2018.11.003.

35. Matas J, Orrego M, Amenabar D, Infante C, Tapia-Limonchi R, Cadiz MI, Alcayaga-Miranda F, González PL, Muse E, Khoury M, Figueroa FE, Espinoza F. Umbilical cord-derived mesenchymal stromal cells (MSCs) for knee osteoarthritis: repeated MSC dosing is superior to a single msc dose and to hyaluronic acid in a controlled randomized Phase I/II trial.
Stem Cells Transl Med. 2019;8(3):215-24. https://doi.org/10.1002/sctm. 18-0053.

36. Song JS, Hong KT, Kim NM, Jung JY, Park HS, Chun YS, Kim SJ. Cartilage regeneration in osteoarthritic knees treated with distal femoral osteotomy and intra-lesional implantation of allogenic human umbilical cord blood-derived mesenchymal stem cells: a report of two cases. Knee. 2019;26(6):1445-50. https://doi.org/10.1016/j.knee.2019.07.017.

37. Gupta PK, Chullikana A, Rengasamy M, Shetty N, Pandey V, Agarwal V, Wagh SY, Vellotare PK, Damodaran D, Viswanathan P, Thej C, Balasubramanian S, Majumdar AS. Efficacy and safety of adult human bone marrow-derived, cultured, pooled, allogeneic mesenchymal stromal cells (Stempeuce ${ }^{\circledR}$ ): preclinical and clinical trial in osteoarthritis of the knee joint. Arthritis Res Ther. 2016;18(1):301. https://doi.org/10.1186/ s13075-016-1195-7.

38. Kuah D, Sivell S, Longworth T, James K, Guermazi A, Cicuttini F, Wang Y, Craig S, Comin G, Robinson D, Wilson J. Safety, tolerability and efficacy of intra-articular Progenza in knee osteoarthritis: a randomized doubleblind placebo-controlled single ascending dose study. J Transl Med. 2018;16(1):49. https://doi.org/10.1186/s12967-018-1420-z.

39. Jo CH, Chai JW, Jeong EC, Oh S, Kim PS, Yoon JY, Yoon KS. Intratendinous injection of autologous adipose tissue-derived mesenchymal stem cells for the treatment of rotator cuff disease: a first-in-human trial. Stem Cells. 2018;36(9):1441-50. https://doi.org/10.1002/stem. 2855.

40. Peretti GM, Ulivi M, De Girolamo L, Meroni V, Lombardo MD, Mangiavini $L$. Evaluation of the use of autologous micro-fragmented adipose tissue in the treatment of knee osteoarthritis: preliminary results of a randomized controlled trial. J Biol Regul Homeost Agents. 2018;32(6 Suppl. 1):193-9.

41. Shapiro SA, Kazmerchak SE, Heckman MG, Zubair AC, O'Connor MI. A Prospective, single-blind, placebo-controlled trial of bone marrow aspirate concentrate for knee osteoarthritis. Am J Sports Med. 2017:45(1):82-90. https://doi.org/10.1177/0363546516662455.

42. Lamo-Espinosa JM, Blanco JF, Sánchez M, Moreno V, Granero-Moltó F, Sánchez-Guijo F, Crespo-Cullel Í, Mora G, San Vicente DD, PompeiFernández O, Aquerreta JD. Phase II multicenter randomized controlled clinical trial on the efficacy of intra-articular injection of autologous bone marrow mesenchymal stem cells with platelet rich plasma for the treatment of knee osteoarthritis. J Transl Med. 2020;18(1):356. https:// doi.org/10.1186/s12967-020-02530-6.

43. Migliorini F, Maffulli N, Baroncini A, Knobe M, Tingart M, Eschweiler J. Matrix-induced autologous chondrocyte implantation versus autologous matrix-induced chondrogenesis for chondral defects of the talus: a systematic review. Br Med Bull. 2021;138(1):144-54. https://doi.org/ 10.1093/bmb/ldab008.

44. Saw KY, Anz A, Siew-Yoke Jee C, Merican S, Ching-Soong Ng R, Roohi SA, Ragavanaidu K. Articular cartilage regeneration with autologous peripheral blood stem cells versus hyaluronic acid: a randomized controlled trial. Arthroscopy. 2013;29(4):684-94. https://doi.org/10.1016/j. arthro.2012.12.008.

45. Avanzi P, Giudici LD, Capone A, Cardoni G, Lunardi G, Foti G, Zorzi C. Prospective randomized controlled trial for patch augmentation in rotator cuff repair: 24-month outcomes. J Shoulder Elbow Surg. 2019;28(10):1918-27. https://doi.org/10.1016/j.jse.2019.05.043.

46. Sadovský P, Musil D, Stehlík J. Pouzití alogenních stepů v chirurgii zkrízených vazů kolenního kloubu - Cást 1 [Allograft for surgical reconstruction of the cruciate ligaments of the knee - part 1]. Acta Chir Orthop Traumatol Cech. 2005;72(5):293-6.

47. Chisari E, Rehak L, Khan WS, Maffulli N. The role of the immune system in tendon healing: a systematic review. Br Med Bull. 2020;133(1):49-64. https://doi.org/10.1093/bmb/ldz040.

48. Huang XP, Sun Z, Miyagi Y, McDonald Kinkaid H, Zhang L, Weisel RD, Li RK. Differentiation of allogeneic mesenchymal stem cells induces immunogenicity and limits their long-term benefits for myocardial repair. Circulation. 2010;122(23):2419-29. https://doi.org/10.1161/ CIRCULATIONAHA.110.955971.

49. Joswig AJ, Mitchell A, Cummings KJ, Levine GJ, Gregory CA, Smith R 3rd, Watts AE. Repeated intra-articular injection of allogeneic mesenchymal stem cells causes an adverse response compared to autologous cells in the equine model. Stem Cell Res Ther. 2017;8(1):42. https://doi.org/10.1186/s13287-017-0503-8. 
50. Boden SD. Multicenter trial of stem cell therapy for osteoarthritis (MILES). ClinicalTrials.gov Identifier: NCT03818737 [cited 28 October 2021]. https://www.clinicaltrials.gov/ct2/show/NCT03818737.

\section{Publisher's Note}

Springer Nature remains neutral with regard to jurisdictional claims in published maps and institutional affiliations.

- fast, convenient online submission

- thorough peer review by experienced researchers in your field

- rapid publication on acceptance

- support for research data, including large and complex data types

- gold Open Access which fosters wider collaboration and increased citations

- maximum visibility for your research: over 100M website views per year

At $\mathrm{BMC}$, research is always in progress.

Learn more biomedcentral.com/submissions 